This is not the version of record. The published version of Umar T., Tahir A., Egbu C., Honnurvali M.S., Saidani M., Al-Bayati A.J. (2021) Developing a Sustainable Concrete Using Ceramic Waste Powder. In: Ahmed S.M., Hampton P., Azhar S., D. Saul A. (eds) Collaboration and Integration in Construction, Engineering, Management and Technology. Advances in Science, Technology \& Innovation (IEREK Interdisciplinary Series for Sustainable Development). Springer, Cham. pp. 157-162. ISBN: 9783030484644 . ISSN: 2522-8714 (print) ISSN: 2522-8722 (electronic) can be found at: https://doi.org/10.1007/978-3-030-48465-1_27 


\title{
Developing a Sustainable Concrete using Ceramic Waste Powder
}

\author{
Tariq Umar ${ }^{1}$, Abdullah Tahir ${ }^{2}$, Charles Egbu ${ }^{3}$ Mohamed Shaik Honnurvali ${ }^{4}$, \\ Messaoud Saidani ${ }^{5}$, Ahmed Jalil Al-Bayati ${ }^{6}$ \\ ${ }^{1}$ and 4 A'Sharqiyah University, Ibra, Oman \\ ${ }^{2}$ University of South Wales, UK \\ ${ }^{3}$ University of East London, UK \\ ${ }^{5}$ Coventry University, UK \\ ${ }^{6}$ Western Carolina University, USA \\ tariqumar1984@gmail.com
}

\begin{abstract}
The change from a traditional utilization based society to a sustainable society is urgently needed because of the contamination of the natural environment, the depletion of the natural resources and the reduced capacity of the final waste disposal arrangements. Concrete is regarded as an advanced and major construction material which needs continuous innovation and improvement to reduce environmental impact. In the future, the demand for concrete will be increasing with the increase in population. This article presents an experimental study of using ceramic waste as a limited replacement with cement in structural concrete. Ceramic waste deposit, on one side, poses a number of environmental challenges, ranging from air, water and soil contaminations but on another side, it has cementitious properties. Concrete mixtures with different percentage of ceramic waste powder were produced, tested and compared in terms of compressive strength. As a result, the maximum compressive strength achieved with a $30 \%$ ceramic waste. The purpose of this study was to examine the performance of cement concrete with different percentage of ceramic waste powder, it needs to be noted that such performance may be varied when the grade of cement or chemical composition of ceramic waste powder will be changed. The long-run performance (after 28 days) of such concrete and especially when used with reinforcement need to be investigated further.
\end{abstract}

Keywords: Concrete technology \& manufacture, Pollution, Sustainability, Natural resources.

\section{Introduction}

Now a day in many developing countries, sustainability is the major issue. The concept of sustainability requires building societies in a specific way so that everyone can live easily without using much of the natural resources. Collective and individual roles and contribution are significantly important in this regard. The United Nations Sustainable Development Goals [1,2] for the next 15 years that include, a) Industry 
innovation and infrastructures and b) Sustainable cities and communities, are closely related to the construction industry. While the advanced and industrialized states are called upon to decrease emission and their part of the utilization of the earth's reserves, including energy, the developing states require to refrain from the mistakes of the past [3]. It is expected that cement production in coming years will significantly increase in developing countries thus the greenhouse emission problem seems to be acute.

Several environmental factors have raised the concern now that the selection of construction materials needs to be also governed by ecological considerations. At the starting of the 20th century, the total earth population was estimated at 1.5 billion, which was raised to 6 billion at the end of the 20th century. It tool approximately, 10,000 years from the last ice age and the earth population was raised to 1.5 billion, however from 1.5 billion to 6 billion growth in population is very significant. Interestingly, at the start of 20th century, only $10 \%$ of the world population was living in the cities, however, in 2001, it is revealed that 3 out of 6 billion people were living in cities [4]. Tragically, the world technological advancements have shown to be destructive due to the facts that all these decisions are normally based on some usual expectation which focus on the profit without considering the long term consequences. Today, approximately $6 \%$ of the total earth flow of materials, which is equal to 500 billion per year, realistically ends up in buyer products. Majority of the remaining portion of the materials are returned in solid, liquid or gas forms of waste. In the past 100 years, climate change and global warming problems have been arises due to the increased emission of greenhouse gases to the atmosphere. In naturefocused industrialization, the environmental factors will be considered as important as of production. Environmental sustainability will be an important element of the whole economy.

Due to several advantages, a concrete requirement is expected to be growing and it is estimated that this requirement will become double in the next 30 years. There is a possibility that this requirement of concrete can be achieved without further addition to green-houses gases if the cement is replaced by another material which has cementing properties. The use of cement concrete in structural results into excellent performance in all modern construction projects around the world and coping with the increased demand for urbanization. Along with this fact, concrete also utilizes the largest portion of natural resources during the manufacturing process of cement. One of the elements which are heavily utilized in the cement production process is the energy. In developing countries, especially those which are struggling with energy and have no renewable sources of energy, the significance of utilizing industrial waste become more. Ordinary Portland cement (OPC) is commonly used on a larger scale in the construction industry. To produces 1 ton this type of cement, the same quantity of $\mathrm{CO}_{2}$ is emitted to the earth atmosphere. Senthamarai and Manoharan [5] noted that the use of different wastes produced by a variety of industrial sectors, in concrete can reduce the impact on the natural environment. 
Construction is a major industry of Oman which account for the 10\% of the total GDP $[6,7]$. The current and future cement requirement in Oman is huge as the infrastructure projects are at a peak. The ongoing and planned development projects in different sectors, including construction, for the financial year 2015-2016 is shown in figure 1. The construction sector projects stand out as the largest one, amounting to US\$ 43.16 Billion. According to the budget report, spending on development projects is estimated at US\$ 3.12 Billion (OMR1.2 Billion), representing the amount to be paid during the year 2017, as the actual work progresses. The cement industry is producing up to $5 \%$ of the total world $\mathrm{CO}_{2}$ emissions [8]. Cement production capacity in Oman currently stands at 8.81Megatton/year [9]. Manufacturing 1 ton of cement needs 4.7 million British Thermal Unit (BTU) of energy, which is roughly equal to 400 pounds of coal, and produces nearly 1 ton of $\mathrm{CO}_{2}[10,11]$. Thus the total production of $\mathrm{CO}_{2}$ by the cement industry in Oman is equal to $8.81 \mathrm{Megatton} /$ year.

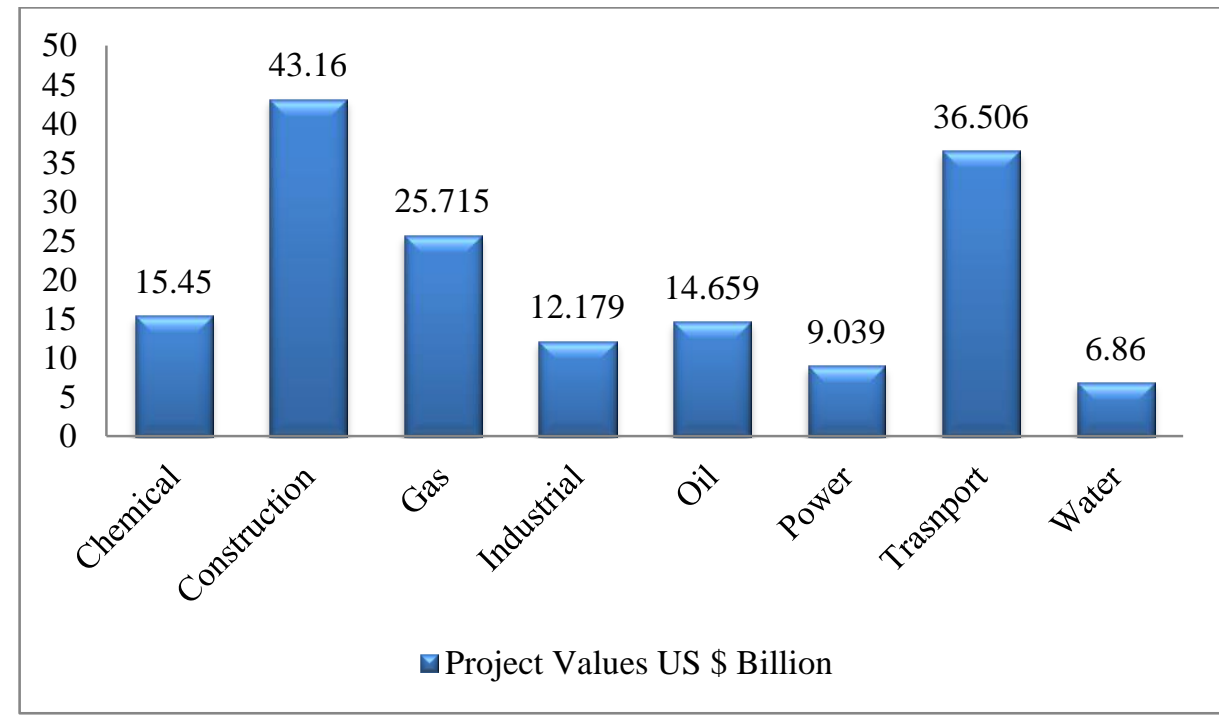

Figure 1: Values of Ongoing and Planned Projects in Different Sectors of Oman [6].

To save the environment from global warming there is a need to replace the cement with a variety of binding materials which have cementitious characteristics like a ceramic waste, hypo sludge, fly ash, silica fume, Ground-granulated blast-furnace slag (GGBS), Metakoline and other industrial waste products. Using these waste materials in construction can reduce the environmental impact. In this regard, the use of ceramic waste in cement concrete is one of the most appropriate approaches. Utilizing ceramic waste in cement concrete can solve two problems. At one side, it will help to effectively dispose-off the ceramic industry waste in construction and at another side, it will help to reduce the use of cement which will further results into reduction of $\mathrm{CO}_{2}$ emission and natural resources [12]. Globally ceramic production is estimated at 100 million ton per year. The waste from the ceramic industry is 
estimated to be $15 \sim 30 \%$ of the total production. It is very difficult to recycle this waste. With the chemical and physical properties, ceramic waste is considered to be durable, hard and highly resistant to biological, chemical and physical degradation forces [13]. The ceramic waste deposit also poses a number of environmental challenges, ranging from air, water and soil contaminations [14].

The consumption of materials used in concrete can be reduced by using advanced concrete technology. Using waste and recycled materials in cement concrete provides several benefits including a reduction in cost, saving energy and reduction in different environmental hazards. The dressing and polishing process of ceramic products result in ceramic waste. During the manufacturing process of ceramic products, $15 \sim 30 \%$ of the waste is produced from the raw materials. Some percentage of this waste is normally utilized at construction projects during exaction and backfilling; however, the remaining is just used for dumping. Such disposal further needs a large area and results in several environmental issues. Raval et al. [12], in their research on ceramic waste concluded that such waste could be utilized in concrete production which can also enhance the compressive strength and other performance. The work conducted by Subaş1 et al [14], on the use of crushed ceramic waste powder as fine aggregates in self-compacting concrete found that the use of waste ceramic powder results into a positive impact on the viscosity of fresh concrete. Rashid et al [15], in their experimental and analytical investigation, conventional aggregate is replaced by different amounts of ceramic waste aggregate. Both the research conducted by Subaş1 et al [14] and Rashid et al [15], however, was not aiming to replace the quantity of cement in concrete.

The chemical composition of ceramic waste may further change this percentage at which the strength is reducing. The earlier research conducted by Torkittikul and Chaipanich [16], on the use of ceramic waste as filler material in ordinary cement and fly-ash concretes observed that the strength of concrete made with ceramic waste was found to be grown with ceramic waste content while the maximum compressive strength was noted when the ceramic waste content was at $50 \%$ of the cement. They further observed that the compressive strength of such concrete was reduced when the percentage of ceramic waste was increased beyond 50\%. In this experimental research, however, the ceramic waste was used as an alternative of fine aggregates rather than cement.

This article presents the results of laboratory experiments of cement concrete with the use of different percentages of ceramic power. The concrete grade selected for the laboratory work was M 25 (IS 456 (2000)) prepared with 0\% - 50\% of ceramic waste powder [17]. The results show that the maximum strength can be obtained with $30 \%$ of ceramic waste powder. 


\section{Methodology}

This research aims to use ceramic waste powder in concrete and to see its performance (compressive strength) at seven and 28 days. The concrete mix used in this research was M 25 (IS 456 (2000)) which was made with different percentage of ceramic waste $(0 \%, 10 \%, 20 \%, 30 \%, 40 \%$, and $50 \%)$. The description of materials used in this work is given as under:

\subsection{Cement:}

The ordinary Portland cement of grade 53 was used in this research. The initial and final setting time test was carried out to know these values. The recorded value for the initial setting time was 35 minutes and the final setting time was 60 minutes. 3.15 was the value of the specific gravity of cement used in this research work.

\subsection{Fine Aggregate:}

The fine aggregate used in laboratory experiments was obtained from a local sand supplier. The specific gravity of fine aggregates was observed to be 2.61 .

\subsection{Coarse Aggregate:}

Well-graded aggregates of size less than $20 \mathrm{~mm}$, with a specific gravity of 2.81 were obtained from a local supplier. The particle size of both fine aggregates and coarse aggregates were checked through the sieve analysis (ASTM C136) as shown in figure $2[18]$.

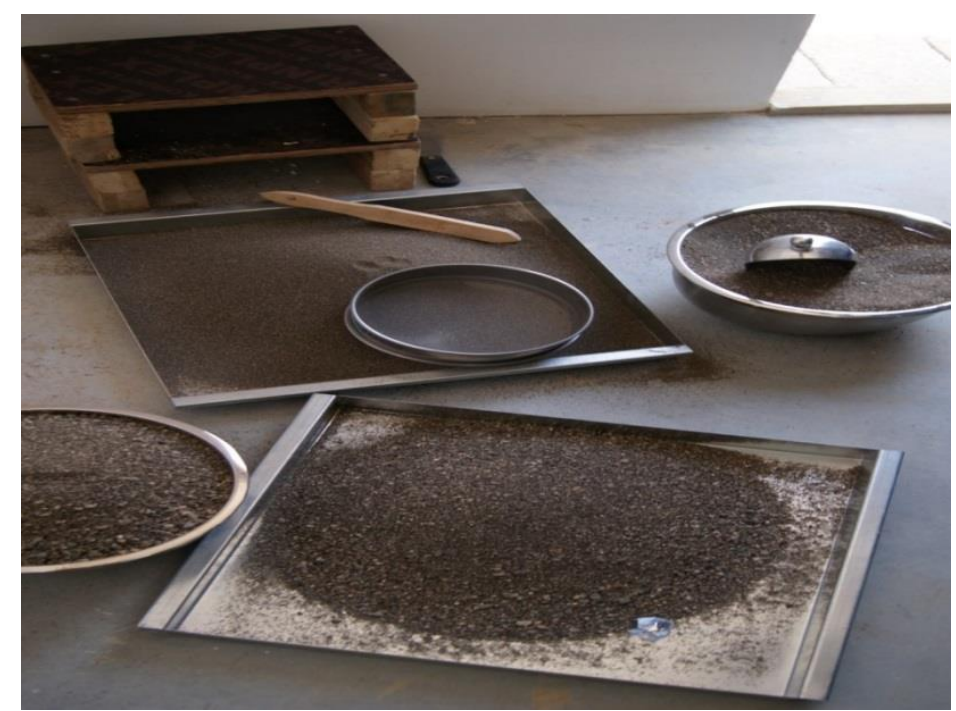

Figure 2: Sieve Analysis for Fine and Coarse Aggregates [18]. 


\subsection{Super-plasticizer:}

For the purpose of improving concrete workability properties, a specific superplasticizer (Conplast-SP430) was used at a rate of 0.5 percent of the weight of the cement.

\subsection{Ceramic Waste:}

The ceramic powder used in the experiment was obtained from Muscat industrial area in Oman. The chemical composition of cement and ceramic powder is used in this research is shown in Table.1.

Table 1- Chemical Characteristics of ceramic powder and cement

\begin{tabular}{|c|c|c|}
\hline $\begin{array}{l}\text { Chemical } \\
\text { composition }\end{array}$ & $\begin{array}{l}\text { Ceramic Powder } \\
(\%)\end{array}$ & Cement (\%) \\
\hline Lime $(\mathrm{CaO})$ & 4.47 & 62.00 \\
\hline Silica $\left(\mathrm{SiO}_{2}\right)$ & 63.30 & 22.00 \\
\hline Alumina & 18.30 & 5.55 \\
\hline Magnesium & 0.73 & 1.00 \\
\hline Calcium sulphate & 4.06 & 4.00 \\
\hline
\end{tabular}

\section{Laboratory Experiment}

To produce a sustainable concrete by utilizing ceramic waste powder to replace some quantity of cement, the different mix was produced with by adding $0 \%, 10 \%, 20 \%$, $30 \%, 40 \%$ and $50 \%$ of ceramic waste powder. To determine the proportion of each material in concrete, in each mix, cement was taken as $250 \mathrm{~kg}$ in each one cubic meter. For increasing the workability of freshly made concrete, super-plasticizer (Conplast-SP430 was added to each mix. For the workability, the slump test was conducted as per ASTM C143 as presented in figure 3. The relative quantities of each material are presented in Table.2. All the required materials were mixed in an automatic mixing machine. The concrete was then poured into the standard moulds of $150 \mathrm{~mm} \times 150 \mathrm{~mm} \times 150 \mathrm{~mm}$ [19] (BS 1881-116:1983). It is ensured that the surface is well finished. The casted samples were demoulded after 24 hours and were kept in the curing tank for 7 and 28 days. The mix proportion for M25 grade of concrete is presented in Table.3. A total of 60 cubes $(10$ cubes for each percentage of ceramic powder) were casted. Half of them were crushed after 7 days of curing and remaining after 28 days of curing. 


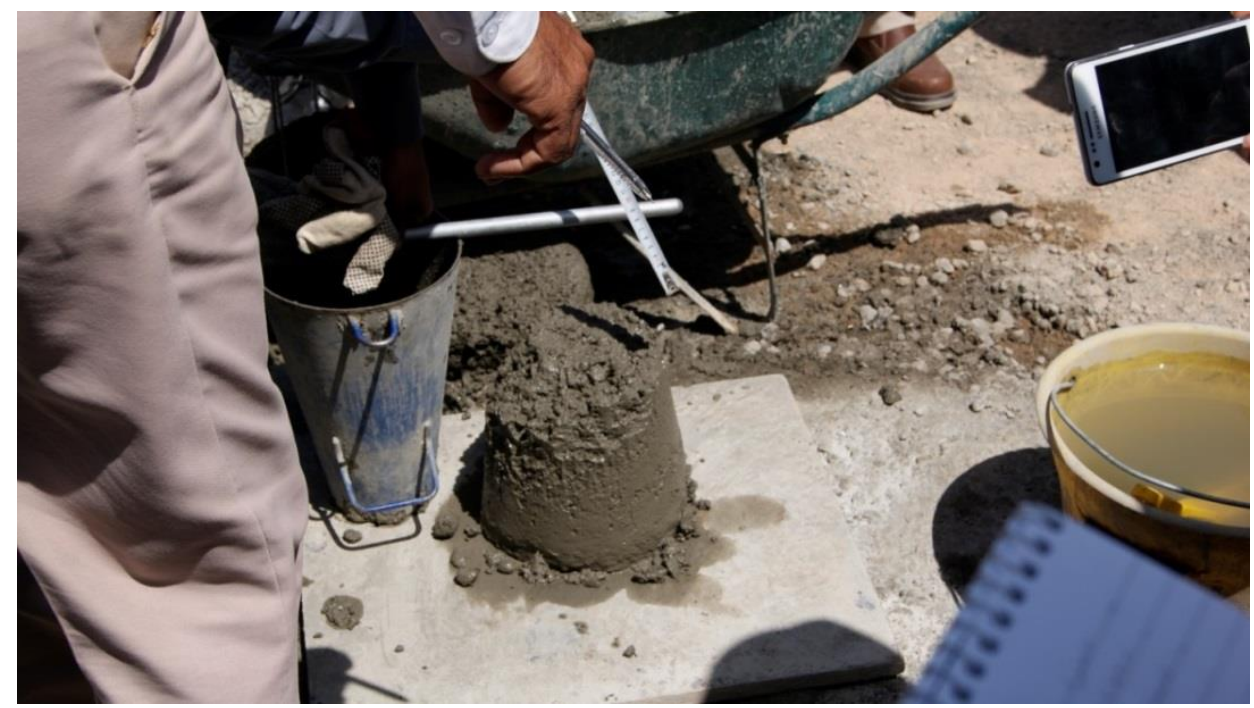

Figure 3: Slump Test for Checking Workability (ASTM C143) [20].

Table 2. Mix Proportion Used in Laboratory Analysis.

\begin{tabular}{lllllll}
\hline Particulars & $\begin{array}{l}\text { Normal } \\
\text { concrete } \\
\text { with 0\% } \\
\text { Ceramic } \\
\text { Waste }\end{array}$ & $\begin{array}{l}\text { Using } \\
\mathbf{1 0 \%} \\
\text { Ceramic- } \\
\text { Waste }\end{array}$ & $\begin{array}{l}\text { Using } \\
\mathbf{2 0 \%} \\
\text { Ceramic- } \\
\text { Waste }\end{array}$ & $\begin{array}{l}\text { Using } \\
\mathbf{3 0 \%} \\
\text { Ceramic- } \\
\text { Waste }\end{array}$ & $\begin{array}{l}\text { Using } \\
\mathbf{4 0 \%} \\
\text { Ceramic- } \\
\text { Waste }\end{array}$ & $\begin{array}{l}\text { Using } \\
\mathbf{5 0 \%} \\
\text { Ceramic- } \\
\text { Waste }\end{array}$ \\
\hline $\begin{array}{l}\text { Cement: } \\
\text { Kg/m }\end{array}$ & 250.00 & 225.00 & 200.00 & 175.00 & 150.00 & 125.00 \\
$\begin{array}{l}\text { Ceramic- } \\
\text { waste: }\end{array}$ & -- & 25.00 & 50.00 & 75.00 & 100.00 & 125.00 \\
$\begin{array}{l}\text { Kg/m } \\
\text { Coarse }\end{array}$ & 1420.00 & 1420.00 & 1420.00 & 1420.00 & 1420.00 & 1420.00 \\
$\begin{array}{l}\text { Aggregate: } \\
\text { Kg/m }\end{array}$ & & & & & & \\
$\begin{array}{l}\text { Fine } \\
\text { Aggregate: }\end{array}$ & 711.00 & 711.00 & 711.00 & 711.00 & 711.00 & 711.00 \\
$\begin{array}{l}\text { Kg/m } \\
\text { Water: }\end{array}$ & 125.00 & 125.00 & 125.00 & 125.00 & 125.00 & 125.00 \\
$\begin{array}{l}\text { Kg/m } \\
\text { Admixture: }\end{array}$ & 1.25 .00 & 1.25 .00 & 1.25 .00 & 1.25 .00 & 1.25 .00 & 1.25 .00 \\
Kg/m
\end{tabular}




\section{Test Results and Discussion:}

\subsection{Compressive Strength:}

After properly curing the prepared concrete cubes for seven and 28 days in the water tank, were then tested for compressive strength through a compression testing machine as shown in figure 4 (BS 1881-116:1983) [19]. The average value of compressive strength was recorded. It was noticed from the results that there is steep growth in compressive strength with the addition of ceramic powder. This is possibly because of the silica content present in the ceramic powder. Beyond $30 \%$ replacement, there is a decrease in strength. This is possibly because of less amount of cement in the mix. Based on this statement it can be concluded that a $30 \%$ replacement is optimum. The results are presented in Figure 5. It can be observed from the figure 5 , that the compressive strength of concrete having ceramic waste powder of up to $40 \%$ reduced from $36.95 \mathrm{MPa}$ to $25.9 \mathrm{MPa}$, which is, however, meeting the minimum requirement of the compressive strength for this grade of concrete. This, however, indicates that increasing the ceramic waste from more than $30 \%$ will result in a reduction in compressive strength. Although it is observed that the variation of ceramic waste can change the strength of concrete, however, the chemical composition of the ceramic-waste can play a significant role. A ceramic waste with a different chemical composition will defiantly give a different strength of concrete.

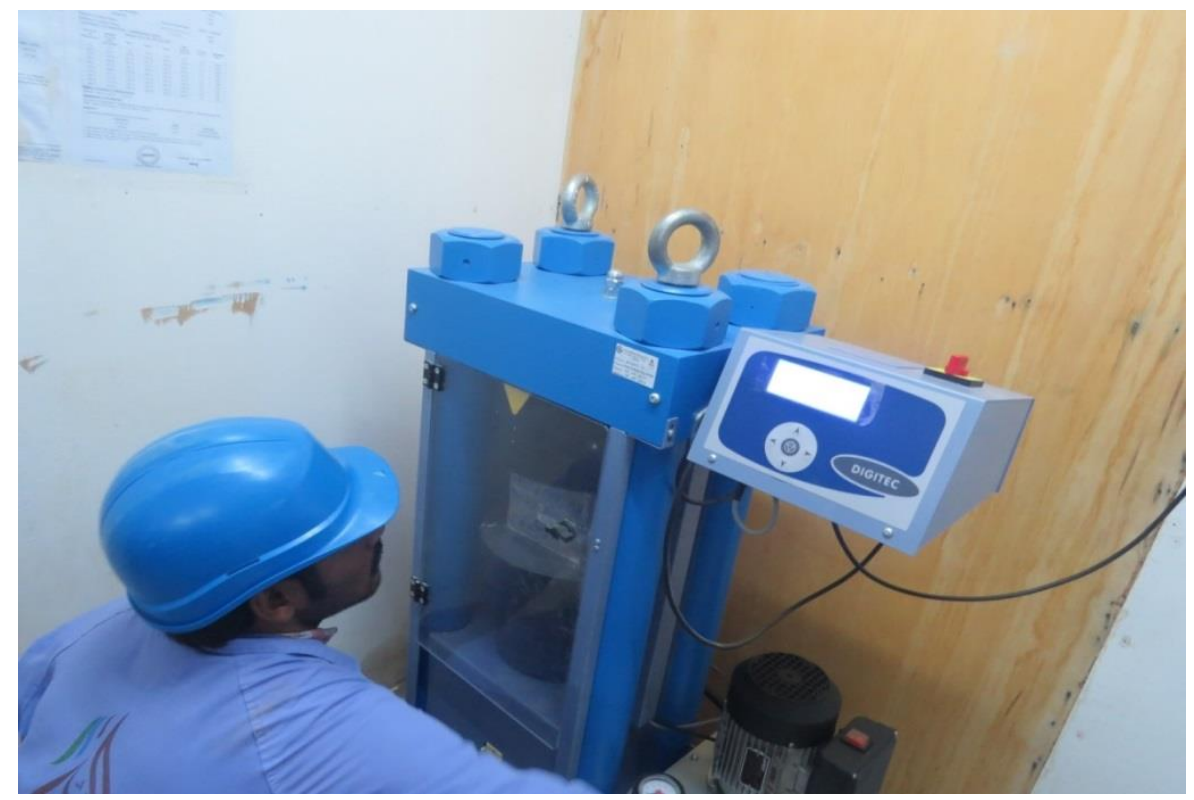

Figure 4: Compaction Test of Different Cube Trough Compaction Testing Machine (BS 1881-116:1983) [19]. 


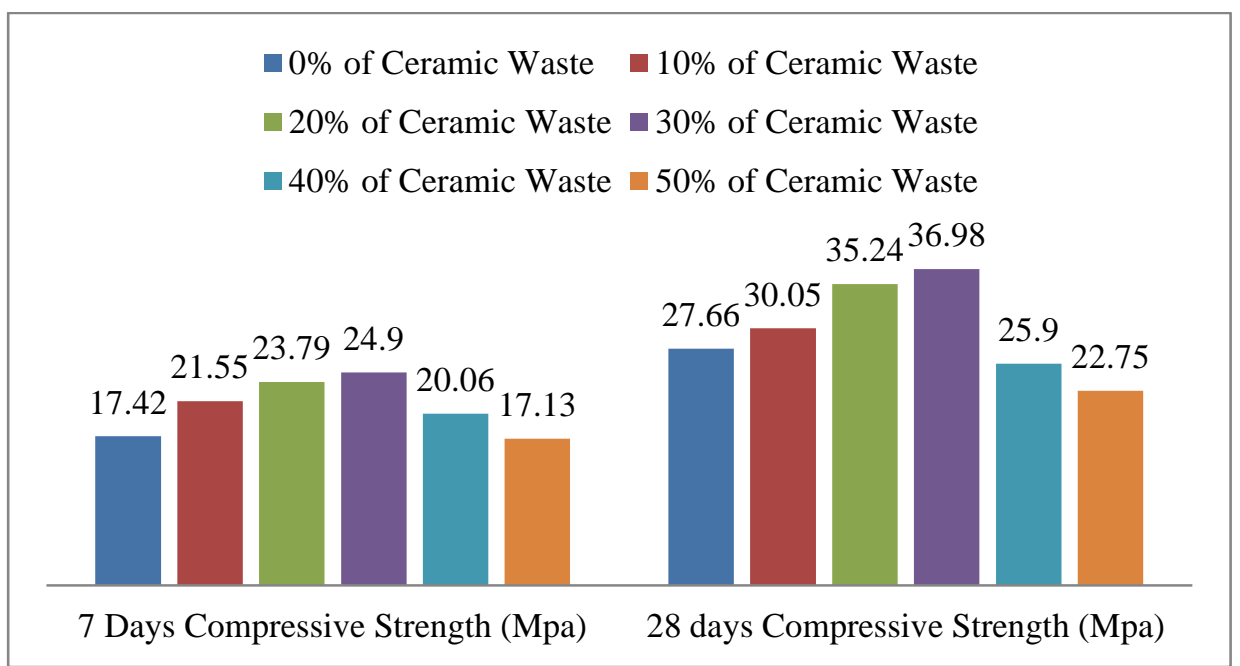

Figure 5: Compressive strength (7 and 28 days) of Concrete with different percentage of Ceramic Waste.

\section{Conclusion:}

It is estimated that at least 18 billion tons of concrete will be required every year after 2050. The ordinary cement which is largely used in concrete production, not only consume a significant share of energy but also produce a considerable quantity of $\mathrm{CO}_{2}$, which result in environmental problems. Concrete is a major construction material which needs continuous innovation and improvement to reduce environmental impact. This article presents the results of laboratory investigation of using ceramic waste to reduce the quantity of cement of a specific grade of concrete and compare its compressive strength. An ordinary portland cement concrete with $0 \%, 10 \%, 20 \%, 30 \%, 40 \%$ and $50 \%$ of ceramic waster powder is prepared and tested for compressive strength. The result shows that the maximum compressive strength of concrete is gained with $30 \%$ of ceramic waste powder. The strength was, however, reducing when the percentage of ceramic waste powder was increased than $30 \%$. By using $30 \%$ of ceramic waste powder in concrete can reduce the use of cement and a similar portion of $\mathrm{CO}_{2}$ emission by cement production will thus reduce. In Oman, the $\mathrm{CO}_{2}$ emission by cement production is currently stood at $8.81 \mathrm{Megaton} / \mathrm{year}, 30 \%$ reduction will bring the emission to 6.167 Megaton/year. The results of the compressive strength of concrete may be different when a different grade of cement or a ceramic waste with different chemical composition will be used. Since ceramic waste deposit poses a number of environmental challenges, ranging from air, water and soil contaminations, thus this is a sustainable solution to unitize such waste. This investigation shows the results of compressive strength after 28 days, it is, therefore, 
necessary that observer the long-run performance of such concrete and especially when used with the reinforcement.

\section{References}

1. UNSDG, 2017 (United Nation Sustainable Development Goals) 2017. New York, USA. See: http://www.un.org/sustainabledevelopment/sustainable-development-goals/ (Accessed 27/08/2017).

2. Umar, T. and Egbu, C., 2018. Global commitment towards sustainable energy. Proceedings of the Institution of Civil Engineers-Engineering Sustainability (pp. 1-9). Thomas Telford Ltd. https://doi.org/10.1680/jensu.17.00059.

3. Umar, T., Egbu, C. and Saidani, M., 2019. A Modified Method for Los Angeles Abrasion Test. Iranian Journal of Science and Technology, Transactions of Civil Engineering, pp.17. https://doi.org/10.1007/s40996-019-00268-w.

4. UN (2002), United Nation, Report on "World Urbanization Prospects", 2002. New York, USA. See: http://www.un.org/esa/population/publications/wup2001/wup2001dh.pdf (Accessed 28/08/2017).

5. Senthamarai, R.M. and Manoharan, P.D., 2005. Concrete with ceramic waste aggregate. Cement and Concrete Composites, 27(9), pp.910-913.

6. Umar, T., 2017. Briefing: Cost of accidents in the construction industry of Oman. In Proceedings of the Institution of Civil Engineers-Municipal Engineer (Vol. 170, No. 2, pp. 68-73). Thomas Telford Ltd. https://doi.org/10.1680/jmuen.16.00032.

7. Umar, T., Egbu, C., Wamuziri, S. and Honnurvali, M.S., 2018. Occupational safety and health regulations in Oman. Proceedings of the Institution of Civil EngineersManagement, Procurement and Law, 171(3), pp.93-99. https://doi.org/10.1680/jmapl.18.00007.

8. EA, 2012. (Earth Institute, 2012). Emissions from the Cement Industry. Earth Institute, Columbia University. New York, USA. See: http://blogs.ei.columbia.edu/2012/05/09/emissions-from-the-cement-industry/ (accessed: 12/10/2017).

9. Global Cement, 2016. Update on cement industry of Oman. Global Cement, Surrey, United Kingdom. See: http://www.globalcement.com/news/itemlist/tag/Oman\%20Cement (accessed 12/10/2017).

10. Pacheco-Torgal, F. and Jalali, S., 2010. Reusing ceramic wastes in concrete. Construction and Building Materials, 24(5), pp.832-838.

11. Umar, T., 2017. Towards a sustainable energy: the potential of biomass for electricity generation in Oman. Proceedings of the Institution of Civil Engineers-Engineering Sustainability (Vol. 171, No. 7, pp. 329-333). Thomas Telford Ltd. https://doi.org/10.1680/jensu.17.00001.

12. Raval, A.D., Patel, D.I.N. and Pitroda, J., 2013. Ceramic Waste: Effective Replacement of Cement For Establishing Sustainable Concrete. International Journal of Engineering Trends and Technology (IJETT). 4(6): pp. 2324 -2329.

13. Awoyeraa, P.O., Akinmusurua, J.O., Ndambukib, J.M. and Lucas, S.S., 2017. Benefits of Using Ceramic Tile Waste for Making Sustainable Concrete. Journal of Solid Waste Technology \& Management, 43(3). p233-241. 
14. Subaş1, S., Öztürk, H. and Emiroğlu, M., 2017. Utilizing of waste ceramic powders as filler material in self-consolidating concrete. Construction and Building Materials, 149, pp.567-574.

15. Rashid, K., Razzaq, A., Ahmad, M., Rashid, T. and Tariq, S., 2017. Experimental and analytical selection of sustainable recycled concrete with ceramic waste aggregate. Construction and Building Materials, 154(1), pp.829-840.

16. Torkittikul, P. and Chaipanich, A., 2010. Utilization of ceramic waste as fine aggregate within Portland cement and fly ash concretes. cement and concrete composites, 32(6), pp.440-449.

17. IS 456 (2000), Indian Standards for Plain and Reinforced Concrete - Code of Practice. Bureau of Indian Standards, New Delhi, India. See: https://archive.org/stream/gov.in.is.456.2000\#page/n3/mode/2up (Accessed 01/02/2017).

18. ASTM (C136). (American Society of Testing and Materials). Standard Test Method for Sieve Analysis of Fine and Coarse Aggregates. Pennsylvania, USA.

19. BS 1881-116:1983. British Standards, Testing concrete - Method for Determination of Compressive Strength of Concrete Cubes. British Standards Institution, London, UK. CI (2017), Ceramic Industry report on global ceramic products, 2017. Michigan, USA. See: http://www.ceramicindustry.com/publications/3 (Accessed 27/08/2017).

20. ASTM (C143). (American Society of Testing and Materials). Standard Test Method for Slump. Pennsylvania, USA. 